\title{
Nesting behaviour and larval biology of Sphex opacus Dahlbom (Hymenoptera, Sphecidae) from Brazil
}

\author{
Sandor C. Buys \\ Departamento de Entomologia, Museu Nacional, Universidade Federal do Rio de Janeiro. Quinta da Boa Vista, São \\ Cristóvão, 20940-040 Rio de Janeiro, Rio de Janeiro, Brasil. E-mail: sbuys@biologia.ufrj.br
}

\begin{abstract}
Aspects of the nesting behaviour of Sphex opacus Dahlbom, 1845 are presented for the first time, based on observations carried out in a coastal habitat from southeastern Brazil. Larval behaviour and development were studied in laboratorial conditions.

KEY WORDS. Biology, reproduction, larva, wasp.
\end{abstract}

RESUMO. Comportamento de nidificação e biologia da larva de Sphex opacus Dahlbom (Hymenoptera: Sphecidae) no Brasil. Aspectos do comportamento de nidificação de Sphex opacus Dahlbom, 1845 são apresentados pela primeira vez, com base em observações feitas em um habitat costeiro do sudeste do Brasil. O comportamento e o desenvolvimento da larva foram estudados em condições de laboratório.

PALAVRAS CHAVE. Biologia, reprodução, larva, vespa.

Sphex Linnaeus, 1758 is a large and widely distributed genus of digger wasps that usually hunt on Tettigoniidae (Ensiferae) to provision the nests. Although the behaviour of some species of Sphex has been comprehensibly studied (TsuneKi 1963, RiBi \& Ribi 1979, Brockmann 1979, 1980, 1985, Chiappa \& Toro 1996), the most remains unknown or poorly known. Herein aspects of the nesting behaviour of the Neotropical species $S$. opacus Dahlbom, 1845 are presented for the first time.

\section{MATERIAL AND METHODS}

The study was carried out in the Restinga de Barra de Maricá (Municipality of Maricá, Rio de Janeiro State, southeastern Brazil). This is a coastal area covered with "restinga", a vegetational formation derived from Tropical Atlantic rain forest that grows in quaternary soil of marine origin. This area was visited every month from May 2000 to May 2001. One adult female was deposited in the entomological collection of the Museu Nacional, Universidade Federal do Rio de Janeiro (MNRJ), Rio de Janeiro, Brazil.

\footnotetext{
RESULTS

Habitat

The nests were observed along the margins of an unpaved road. In this site, the soil was composed of clay and sand compacted. Usually, there was no vegetation around the nests, but, when present, the vegetation was composed of small herbaceous plants, which did not shadow the nests. Thus, the most of the nests remained exposed to the sun the major part of the day.
}

\section{Reproductive annual pattern}

Nesting females were found from May to August 2000. In September 2000, nests were not observed, only one female flying around. Females in nest activity were observed again in April 2001. These observations suggest a seasonal pattern of reproduction, restricted to the coldest months of the year.

\section{Nest structure}

The nests are multicellular, consisting of a cylindrical principal tunnel transversal to the ground, with about $1.5 \mathrm{~cm}$ in diameter $(\mathrm{n}=3)$ and $11-16 \mathrm{~cm}$ in depth $(\mathrm{n}=3)$, and secondary tunnels, which part from the principal tunnel and reach the cells. The cells are broader than the tunnels and parallel to the soil. From three excavated nests, two bore two cells and one bore one cell. However, all these nests were active still, and possibly they should be increased with new cells. The earth excavated from the nests usually forms a mound, which remains in a sector concentric to the nest entrance. Accessory burrows were not observed.

\section{Digging behaviour}

In order to dig the nest, the female cuts the soil with the mandibles, holds a portion of earth between the forelegs and the head, and walks backward. In this moment, she maintains the mandibles open, apparently to help in the holding of the earth. When she arrives at $2-4 \mathrm{~cm}$ from the nest entrance, she throws the earth backward beneath the body, with a flip of the head and forelegs. The earth reaches up to $4 \mathrm{~cm}$ beyond the wasp body, but usually this distance is shorter. Commonly, the wasp, immediately after throws the earth, synchronically moves 
the legs backward once more, as she does when she throws the earth. The function of this behaviour was not found. After digs for some time, the female scatters the mound of earth that accumulates around the nest due the excavation. In order to scatter the earth, the female walks backward and uses the forelegs to throw earth backward beneath the body and, at the same time, she uses the hindlegs to scatter earth to the sides. The distance and the trajectory the female walks scattering earth vary along the excavation of a cell. In one case, the female in the early excavation walked in a curved trajectory with about $10-13 \mathrm{~cm}$ long. After this, she scattered earth walking in a straight trajectory with about $9 \mathrm{~cm}$ long.

It was not observed males near to the nest during the excavation or provisioning of the nest. Aggregations of nesting females were not observed.

\section{Provision of the nest}

All the observed preys belonged to the family Tettigoniidae (Ensifera). From 16 collected preys only two were adult. Two fully provisioned cells were collected, one bore five preys and other bore eight preys. In one case, the prey bearing egg was very larger than the others and the unique adult katydid found in the cell. But the other three preys bearing egg were little nymphs. Therefore, the females seem not to select a larger prey to oviposit.

\section{Prey manipulation}

The female carries the prey in flight to the nest surroundings, grasping her antennas with the mandibles. When she lands on the ground, does not release the prey antennas and walks to the nest; the prey remains beneath the wasp body. She leaves the prey near to the nest entrance and enters the nest walking forward. After some time, she comes partially out from the nest, walking forward, grasps the prey's antennas with the mandibles, and pulls her to the nest interior, walking backward. The female oviposits inside the nest, in the first hunted prey. The egg is placed transversally on the ventral portion of the prey thorax, one extremity of the egg is attached to a point near the junction of the coxa with the body. The preys are deposited in the cell with the head turned to the bottom. The wasp permanently paralyses the preys, which remain able to eliminate faeces and slightly moving the antennas and the mouthparts.

\section{Temporary closing of the nest}

The females temporarily close the cell after complete the excavation and after put each prey inside the nest. In order to temporarily close the cell, the female uses the earth that remains on the nest entrance due the excavation. The female throws the earth to the burrow with movements identical to those she made when she digs the nest. After that, she enters the nest and emits a set of buzzing sounds, probably due she is compacting the earth. One female closed not only the cell, but also the entire principal tunnel of the nest after put the first prey, a small immature tettigoniid. This female behaves in a way somewhat different from those previously described. She threw the earth from the mound resulting from the excavation to a point nearer to the nest entrance, not directly to her interior. Then, she entered the nest, came out, and threw the earth to the interior of the nest. This female was observed late in the afternoon, and apparently she was ending her nesting activity, then a different type of plug was done to protect the nest during the night.

After close the nests, the females did not compact the earth, nor put stones, leaves or other objects on the nest entrance.

\section{Development and behaviour of the larva in laboratorial conditions}

The eggs are yellow, cylindrical with extremities rounded, slightly curved, with about $5 \mathrm{~mm}$ long. From four eggs brought to the laboratory two hatched. They hatched in the second or third days after the oviposition. Soon after hatching, the larva inserts the anterior part of the body in the membranaceous region below one of the prey foreleg, where the egg had been attached. During the first day of development, she remains immobile in the same position, consuming the prey. In the second day of development, before completely consuming the first prey, she abandoned her body and starts to consume partially others preys. She spends some hours consuming each prey, without a detectable pattern of prey selection. The larva remains more time in the first prey, in which the egg was placed, probably because she needs to reach a certain degree of development to gain independence and being able to abandon that prey. The larva starts to feed the preys in the abdomen or in the junction of the leg. with the body. The feeding phase is very rapid. One larva in the third day after the egg hatching, have already fully consumed five nymphs and, soon after that, she starts to spin her silky cocoon. In one of the observed cases, the larva consumed even the harder parts of the exoesqueleton of the preys.

\section{DISCUSSION}

The behavioural patterns of nest excavation and prey transport are in general similar in distinct species of Sphex (Tsuneki 1963, Ribi \& Ribi 1979, Brockmann 1980, Genise 1980, Evans et al. 1982, Chiappa \& Toro 1996). However, the use of the hindlegs to scatter the earth excavated from the nest, as herein described in S. opacus, apparently was observed only by GENISE (1980) in S. argentinus Taschenberg, 1869 and S. ichneumoneus (Linnaeus, 1758).

The behaviour of temporary closing of the nest is quite variable among species of Sphex. GENISE (1980), in his behavioural revision of the genus, lists three species similar to $S$. opacus in temporary plugging the cell during the provisioning of the nest (S. ichneumoneus; S. argentatus Fabricius, 1787; and S. inusitatus fukuiensis Tsuneki, 1957) and two species that plug the nest externally during the night [S. ephippium Smith, 1856 and $S$. (Fernaldina) lucae Saussure, 1867], as apparently S. opacus does.

The immature $S$. opacus is different from other Sphecidae, as Isodontia auripes (Fernald, 1906) and Podium rufipes Fabri- 
cius, 1804 (KRombein 1970), in abandoning the first prey before it has been totally consumed and consuming partially several preys at the same time.

\section{ACKNOWLEDGEMENTS}

I thank Cinara de Andrade Silva for helping in the field work and Sérvio Túlio do Amarante for identifying the wasp.

\section{REFERENCES}

Brockmann, H.J. 1979. Nest-site selection in the great golden digger wasp, Sphex ichneumoneus L. (Sphecidae). Ecological Entomology, London, 4: 211-224.

Brockmann, H.J. 1980. The control of nest depth in the digger wasp (Sphex ichneumoneus). Animal Behaviour, London, 28: 426-445.

Brockmann, H.J. 1985. Provisioning behavior of the great golden digger wasp, Sphex ichneumoneus (L.) (Sphecidae). Journal of the Kansas Entomological Society, Manhattan, 58 (4): 631-655.

Chiappa, E.; C. Alfaro \& H. Toro. 1996. Comportamiento de nidi- ficación de Sphex latreillei Lepeletier (Hymenoptera: Sphecidae). Acta Entomologica Chilena, Santiago, 20: 83-97.

Evans, H.E.; A.W. Hook \& R.W. MatThews. 1982. Nesting behaviour of Australian wasps of the genus Sphex (Hymenoptera, Sphecidae). Journal of Natural History, London, 16 (2): 219225.

Genise, J.F. 1980. Comportamiento de nidificación de Sphex argentinus Tasch. y S. dorsalis Lep. (Hymenoptera, Sphecidae). Revision de esta actividad en el genero. Revista de la Sociedad Entomológica Argentina, Buenos Aires, 39 (3-4): 251262.

Krombern, K.V. 1970. Behavioral and life-history notes on three Floridian solitary wasps (Hymenoptera: Sphecidae). Smithsonian Contributions to Zoology, Washington, 46: 1-26.

Ribi, W.A \& L. Ribi. 1979. Natural history of the Australian digger wasp Sphex cognatus Smith (Hymenoptera, Sphecidae). Journal of Natural History, London, 13 (6): 693-701.

TsunekI, K. 1963. Comparative studies on the nesting biology of genus Sphex (s.l.) in East Asia. Memoirs of the Faculty of the Liberal Arts, Fukui University, Series II, Natural Sciences, Fukui, 13: 13-78.

Received in 10.I.2005; accepted in 17.VIII.2005. 